\title{
Changes in Births by Month: United States, January 2019-June 2021
}

\author{
Brady E. Hamilton, Ph.D., Michelle J.K. Osterman, M.H.S., and Joyce A. Martin, M.P.H., \\ Division of Vital Statistics, National Center for Health Statistics
}

\section{Ahstract}

Objective-This report presents provisional 2021 and final 2020 and 2019 data on changes in the number of U.S. births by race and Hispanic origin of mother, and by month of birth and state for January through June of 2020 and 2021.

Methods - Data are based on all birth certificates registered to U.S. residents in the 50 states and the District of Columbia (D.C.); data for 2021 are provisional and data for 2020 and 2019 are final. Changes in the number of births by month (from January through June) from 2020 to 2021 by race and Hispanic-origin group are compared with changes occurring from 2019 to 2020 . Changes in the number of births for the first half of the year by race and Hispanic origin and by state are also compared for the periods 2020 to 2021 and 2019 to 2020 .

Results-From 2020 to 2021, the number of births for the United States declined for January (9\%), February (2\%), and May (1\%) and rose by less than $1 \%$ for March (nonsignificantly), April (1\%), and June (3\%). Although the decline in the number of births for the first half of $2021(2 \%)$ was the same as the decline in births for the first half of 2020 , it was largely the result of the $9 \%$ decline in births in January and was less than the decline for the second half of 2020 (5\%). Births declined for all race and Hispanic-origin groups in the first half of 2021, with declines ranging from less than $1 \%$ (not significant) for non-Hispanic White women to $8 \%$ for
non-Hispanic Asian women. Births declined in 19 states and D.C. in the first half of 2021 and increased in 4 states.

Keywords: birth certificate $\cdot$ maternal race and Hispanic origin $\bullet$ state $\bullet$ National Vital Statistics System

\section{Introduction}

In 2021, the COVID-19 pandemic continued into a second year, with a continuing impact on vital events. A recent report that analyzed trends in births in the United States based on provisional 2020 data revealed that the number of births declined for each month from 2019 to 2020, with larger declines observed for those months in the second half of $2020(6 \%)$ compared with the first half of the year (2\%) (1). Births declined for all race and Hispanic-origin groups in both the first and second halves of 2020, with larger declines in the second half of the year compared with the first half for all groups. In addition, the number of births declined for all states in the second half of 2020, compared with declines for only 20 states in the first half of 2020 and 9 states in the second half of 2019 compared with 2018.

This report describes changes occurring in the number of U.S. births overall and by race and Hispanic origin by month from January through June and for the first 6 months of 2021 compared with the same period for 2020, and changes in the number of births by state of residence for the first half of 2021 compared with 2020.

\section{Methods}

Data for 2021 are based on $99.92 \%$ of all birth records received and processed by the National Center for Health Statistics as of September 21, 2021 (1-6). The provisional number of 2021 births are compared with final 2020 birth counts. Changes in final birth counts from 2019 to 2020 are also described.

Hispanic origin and race are reported separately on the birth certificate. Data shown by Hispanic origin include all people of Hispanic origin of any race. Data for non-Hispanic people are shown separately for each single-race group. Data by race are based on the revised standards issued by the Office of Management and Budget in 1997 (6). The race and Hispanic-origin groups shown are non-Hispanic single-race White, non-Hispanic single-race Black, non-Hispanic single-race American Indian or Alaska Native (AIAN), non-Hispanic single-race Asian, non-Hispanic single-race Native Hawaiian or Other Pacific Islander (NHOPI), and Hispanic. For brevity, text references to race omit the term "single race" (7).

The number of births for February 2020 was adjusted to account for the additional day in February 2020 (February 29, leap day), compared with February 2021 and 2019. Both observed and adjusted numbers are shown for February 2020 in Table 1; text comparisons are based on the adjusted February 2020 number of births. The number of births for the total of the first 6 months of 2020 was not adjusted for 
leap day due to the relatively small impact of the additional births for February 29.

Births by state by month are not analyzed because of the small number of births by month for some states.

The completeness of the provisional birth counts for nearly all states and months (including May and June) was $99 \%$ to $100 \%$. The completeness level for Alaska was $100 \%$ for January through April 2021 but was 50\% for May and 36\% for June, for a total completeness level of $80 \%$ for the first 6 months of 2021 $(3,4)$. Given the comparatively low level of completeness, data for Alaska are not shown separately but are included in the national totals due to the relatively small impact of Alaska data on the national estimates (Alaska comprised $0.3 \%$ of all 2020 births) $(3-5,7)$.

All changes in the number of births and differences in the changes shown in this report are statistically significant at the 0.05 level based on a chi-squared test, unless noted otherwise.

\section{Results}

\section{Changes in the number of births by month}

- During the first half of 2021, the number of births declined from 2020 levels in January (9\%) and February $(2 \%)$, but then rose slightly in March (nonsignificantly by less than $1 \%$ ) and April (1\%), declined again in May (1\%), and then rose in June (3\%) (Table 1, Figure 1). In contrast, from 2019 to 2020, the number of births declined for each month of the first half of the year, with declines ranging from $1 \%$ to $5 \%$ and the largest declines observed for February (adjusted), April, and May.

- The total decline in the number of births between 2020 and 2021 for the first half of the year (2\%) was the same as the decline observed between the first half of 2019 and 2020, but less than the $5 \%$ decline in births based on final data for the second half of 2020
(7). The $2 \%$ decline in births for the first half of 2021 was largely driven by the $9 \%$ decline in births for January.

\section{Changes in the number of births by maternal race and Hispanic origin}

- The largest declines in the number of births by month for the first 6 months of 2021 were observed in January for non-Hispanic White (7\%), non-Hispanic Black (11\%), Hispanic (11\%), and non-Hispanic Asian (19\%) women (Table 1). For non-Hispanic AIAN and non-Hispanic NHOPI women, the largest declines were observed in May (12\%) and February $(19 \%)$, respectively.

- The decline in births for the first half of 2021 compared with the same time period in 2020 was less than $1 \%$ (not significant) for non-Hispanic White women, $3 \%$ for Hispanic women, $5 \%$ for non-Hispanic Black and non-Hispanic NHOPI women, $6 \%$ for

Figure 1. Percent change in number of births, by month: United States, 2019 and 2020 final and 2021 provisional

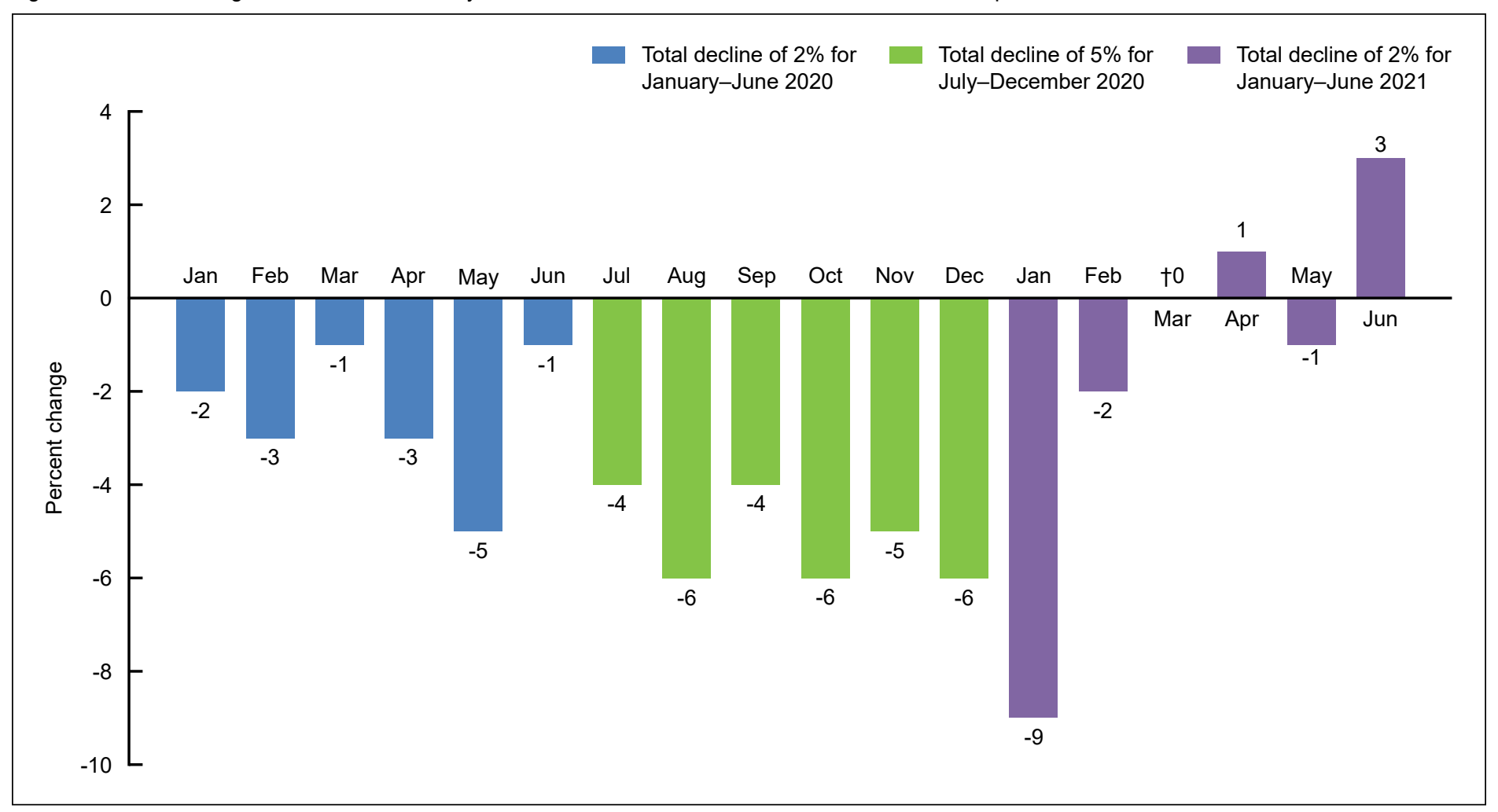

$\dagger$ No significant change $(p<0.05)$

NOTE: Number of births for February 2020 was adjusted for leap day, February 29

SOURCE: National Center for Health Statistics, National Vital Statistics System, Natality. 
non-Hispanic AIAN women, and 8\% for non-Hispanic Asian women (Table 1, Figure 2). In comparison, declines in the number of births for the first half of 2020 compared with the same period in 2019 were smaller for most groups, ranging from less than $1 \%$ (not significant) for Hispanic women to $6 \%$ for non-Hispanic AIAN women (same percentage difference as 2020 and 2021).

\section{Decline in number of births by state}

- Nineteen states and the District of Columbia (D.C.) reported declines in the number of births in the first half of 2021 compared with the first half of 2020 (Table 2, Figure 3); declines in an additional 17 states were not significant. (Births by state by month are not analyzed because of the small number of births by month for some states.) The largest declines were seen in New Mexico (5\%) and D.C. (9\%).
- The number of births in the first half of 2021 increased in four states: Connecticut (3\%), Idaho (3\%), Tennessee (2\%), and New Hampshire (5\%) (Table 2); nine states reported increases that were not significant.

- In comparison, for the first half of 2020 , the number of births declined for 20 states ( 23 additional states reported nonsignificant declines); 7 states reported nonsignificant increases in the first half of 2020 .

- Births in 13 states declined for the first 6 months of both 2020 and 2021. Births declined in an additional 18 states in both years, but one or both declines for these states were not significant.

- One state (New Hampshire) reported increases in the number of births in the first 6 months of both 2020 and 2021 (the increase in 2020 was not significant).

\section{Summary}

For the first 6 months of 2021, compared with the same period in 2020, the number of births declined for January (9\%), February (adjusted) $(2 \%)$, and May (1\%), and rose in March (nonsignificantly), April (1\%), and June (3\%). Overall, the number of births for the first half of 2021 declined by $2 \%$ (due largely to the $9 \%$ decline in births for January), the same as the decline observed for the first half of 2020, but less than the decline observed for the second half of 2020 (5\%) (7). Births declined in the first half of 2021 for all race and Hispanic-origin groups, with declines ranging from less than a nonsignificant $1 \%$ for non-Hispanic White women to $8 \%$ for non-Hispanic Asian women. In the first half of 2021, the number of births declined for 19 states and D.C. and increased in 4 states, compared with declines in 20 states and no increases in the first half of 2020 .

Figure 2. Percent change in number of births, by race and Hispanic origin: United States, January-June 2020 final and 2021 provisional

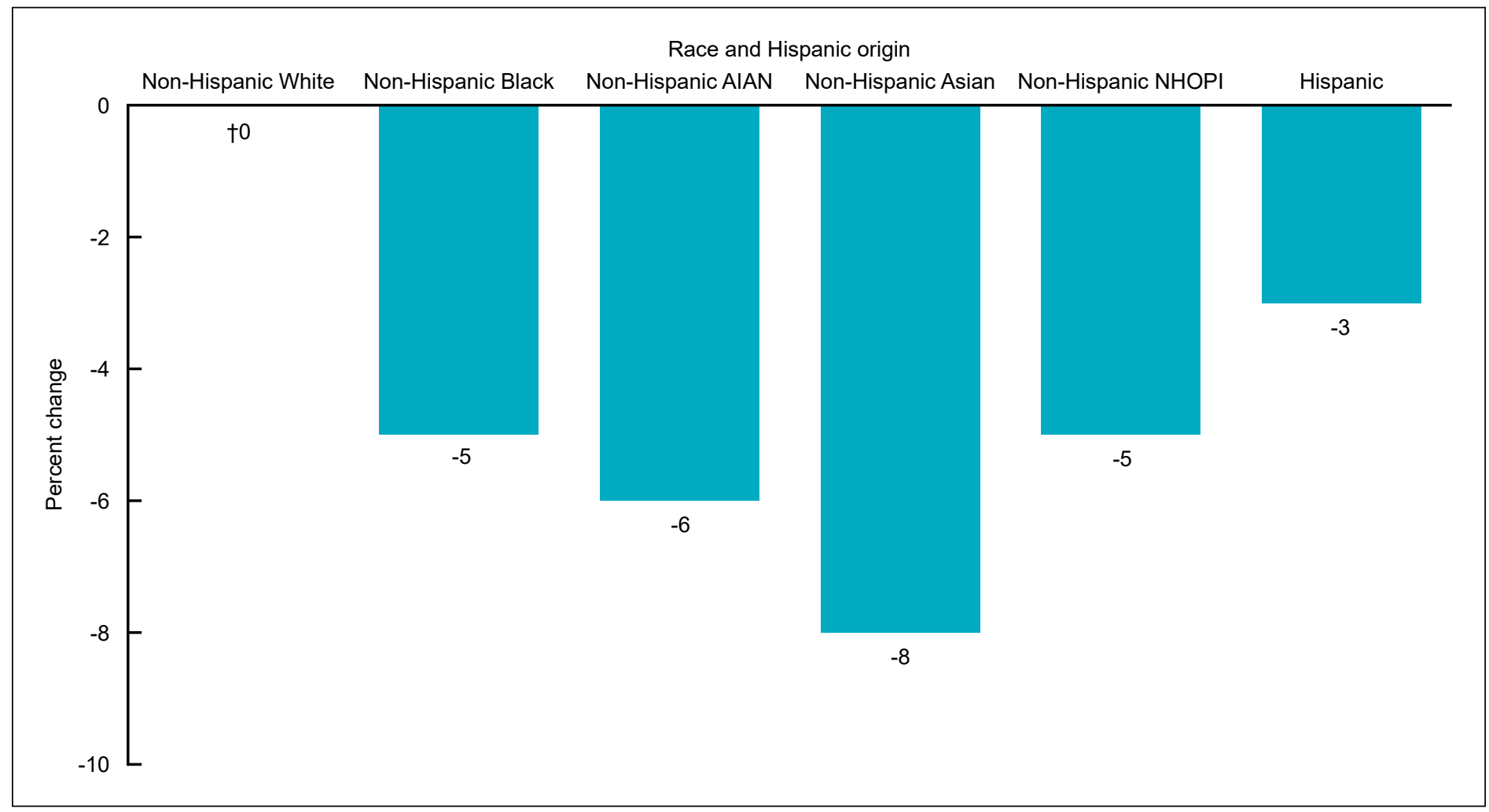

† No significant change $(p<0.05)$.

NOTES: AIAN is American Indian or Alaska Native. NHOPI is Native Hawaiian or Other Pacific Islander. SOURCE: National Center for Health Statistics, National Vital Statistics System, Natality. 
Figure 3. Percent change in number of births, by state of residence: United States, January-June 2020 final and 2021 provisional

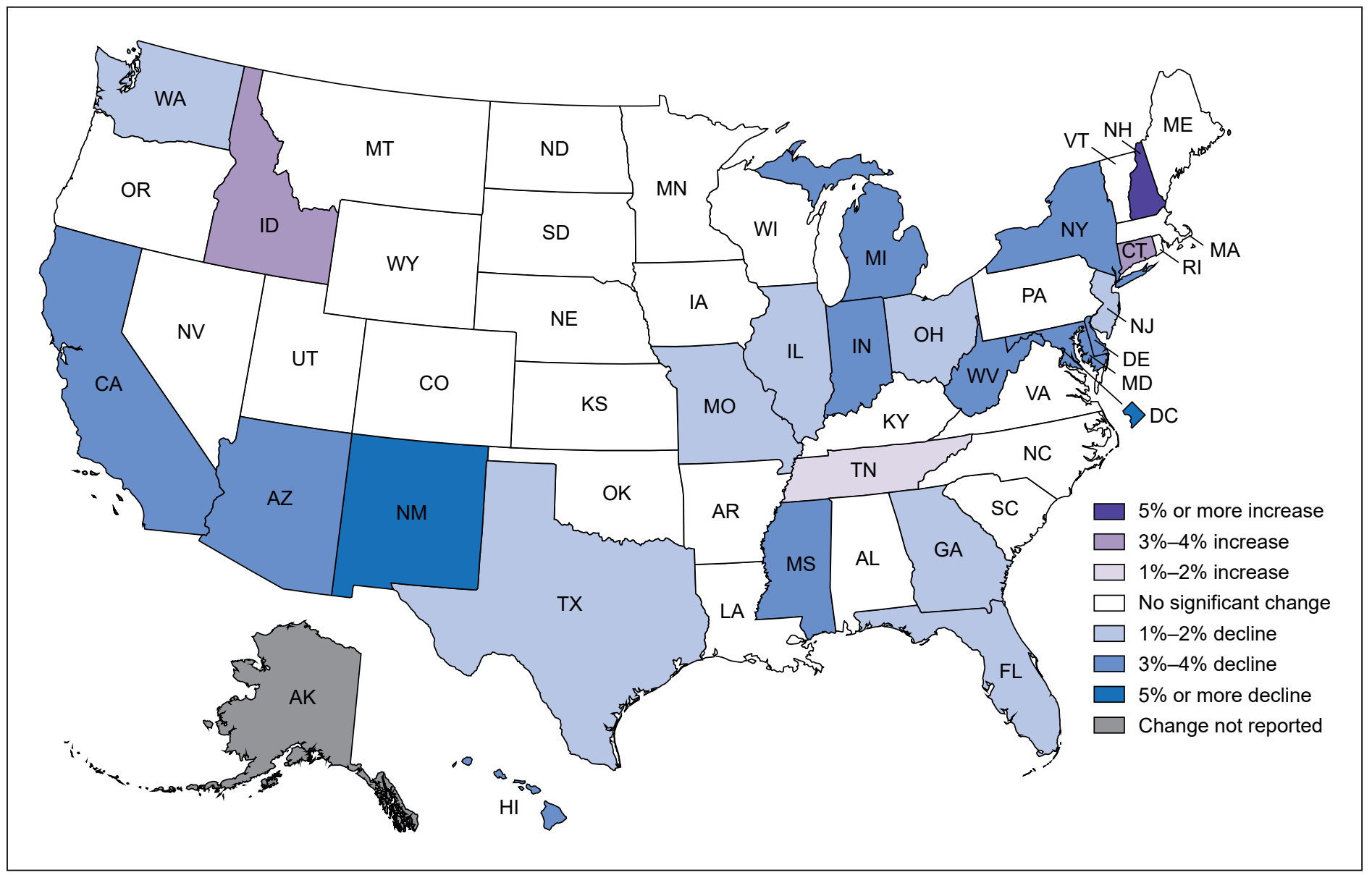

SOURCE: National Center for Health Statistics, National Vital Statistics System, Natality.

From 2015 to 2019, births declined $2 \%$ annually for both the first half and second half of each year. Although the overall relative decline in births for the first half of 2021 was the same as that for the first half of each of the prior 5 years, the sharp decline in births in January and more moderate decline in February of 2021 followed by generally increasing trends beginning in March, are not consistent with those of recent years in which changes in births by month were more moderate. This difference between patterns seen for the first 6 months of 2021 and earlier years suggests that the magnitude of the downward trend seen in the second half of 2020 and January of 2021 may have begun to wane and declines in the number of births may be returning to prepandemic levels. However, ongoing evaluation of trends in births by month will continue to determine whether the changes observed for the first half of 2021 will continue into the second half of the year.

\section{References}

1. Hamilton BE, Osterman MJK, Martin JA. Declines in births by month: United States, 2020. Vital Statistics Rapid Release; no 14. Hyattsville, MD: National Center for Health Statistics. June 2021. DOI: https://dx.doi.org/10.15620/cdc:106116.

2. Driscoll AK, Osterman MJK, Hamilton BE, Valenzuela CP, Martin JA. Quarterly provisional estimates for selected birth indicators, Quarter 1, 2019-Quarter 2, 2021. National Center for Health Statistics. National Vital Statistics System, Vital Statistics Rapid Release Program. 2021. Available from: https://www.cdc.gov/nchs/nvss/vsrr/ natality-dashboard.htm.
3. National Center for Health Statistics, National Vital Statistics System. Provisional estimates for selected maternal and infant outcomes by month, 2018-2021. Hyattsville, MD. Available from: https://www.cdc. gov/nchs/covid19/technical-notesoutcomes.htm.

4. National Center for Health Statistics. Quarterly provisional estimatesTechnical Notes-Natality, Quarter 2, 2021. Available from: https://www.cdc.gov/nchs/nvss/vsrr/ natality-technical-notes.htm.

5. National Center for Health Statistics, National Vital Statistics System. Maternal and infant characteristics among women with confirmed or presumed cases of coronavirus disease (COVID-19) during pregnancy - Technical Notes. Available from: https://www.cdc.gov/ nchs/covid19/technical-linkage.htm. 
6. Office of Management and Budget. Revisions to the standards for the classification of federal data on race and ethnicity. Fed Regist 62(210):58782-90. 1997. Available from: https://www.govinfo.gov/ content/pkg/FR-1997-10-30/pdf/ 97-28653.pdf.

7. Osterman MJK, Hamilton BE, Martin JA, Driscoll AK, Valenzuela CP. Births: Final data for 2020.

National Vital Statistics Reports; vol 70 no 17. Hyattsville, MD: National Center for Health Statistics. 2022.

DOI: https://dx.doi.org/10.15620/ cdc: 112078 .

\section{List of Detailed Tahles}

\section{Report tables}

1. Births, by race and Hispanic origin of the mother and month of birth: United States, January-June, final 2019 and 2020, and provisional 2021, and percent change in births from 2019-2020 and 2020-2021. .

2. Births: United States and each state, January-June, final 2019 and 2020, and provisional 2021, and percent change in births from January-June 2019-2020 and 2020-2021 . . . . . . 
Table 1. Births, by race and Hispanic origin of the mother and month of birth: United States, January-June, final 2019 and 2020, and provisional 2021, and percent change in births from 2019-2020 and 2020-2021

\begin{tabular}{|c|c|c|c|c|c|c|c|c|}
\hline $\begin{array}{c}\text { Race and Hispanic origin of } \\
\text { mother and year }\end{array}$ & $\begin{array}{l}\text { January- } \\
\text { June }\end{array}$ & January & $\begin{array}{l}\text { February } \\
\text { (observed) }\end{array}$ & $\begin{array}{l}\text { February } \\
\text { (adjusted) }^{1}\end{array}$ & March & April & May & June \\
\hline All races and origins ${ }^{2}$ & \multicolumn{8}{|c|}{ Number } \\
\hline $2021^{3}$. & $1,748,768$ & 276,980 & 266,107 & 266,107 & 302,137 & 292,454 & 299,308 & 311,782 \\
\hline 2020. & $1,783,124$ & 304,722 & 282,654 & 272,907 & 301,625 & 290,478 & 301,481 & 302,164 \\
\hline 2019. & $1,814,497$ & 310,872 & 279,963 & 279,963 & 304,237 & 298,947 & 316,386 & 304,092 \\
\hline \multicolumn{9}{|l|}{ Non-Hispanic, single race ${ }^{4}$} \\
\hline \multicolumn{9}{|l|}{ White: } \\
\hline $2021^{3}$ & 914,813 & 142,083 & 138,803 & 138,803 & 159,055 & 153,980 & 156,969 & 163,923 \\
\hline$\ldots \ldots \ldots$ & 916,986 & 152,519 & 143,712 & 138,756 & 155,981 & 150,953 & 156,888 & 156,933 \\
\hline 2019. & 937,741 & 156,819 & 142,992 & 142,992 & 157,502 & 156,516 & 165,587 & 158,325 \\
\hline \multicolumn{9}{|l|}{ Black: } \\
\hline $2021^{3}$ & 245,753 & 41,310 & 38,628 & 38,628 & 41,952 & 39,810 & 40,936 & 43,117 \\
\hline$\ldots \ldots$ & 259,759 & 46,356 & 42,037 & 40,587 & 43,591 & 41,395 & 42,999 & 43,381 \\
\hline$\ldots \ldots \ldots \ldots \ldots \ldots \ldots$ & 262,114 & 47,486 & 41,497 & 41,497 & 43,583 & 42,151 & 44,584 & 42,813 \\
\hline \multicolumn{9}{|l|}{ American Indian or Alaska Native: } \\
\hline $2021^{3} \ldots \ldots \ldots \ldots \ldots \ldots \ldots$ & 12,498 & 2,135 & 1,932 & 1,932 & 2,181 & 2,098 & 1,961 & 2,191 \\
\hline$\ldots \ldots \ldots \ldots \ldots \ldots$ & 13,234 & 2,292 & 2,048 & 1,977 & 2,213 & 2,195 & 2,240 & 2,246 \\
\hline 2019 & 14,013 & 2,525 & 2,182 & 2,182 & 2,332 & 2,293 & 2,382 & 2,299 \\
\hline \multicolumn{9}{|l|}{ Asian: } \\
\hline$\ldots \ldots \ldots \ldots$ & 102,279 & 15,658 & 15,410 & 15,410 & 18,019 & 17,482 & 17,552 & 18,158 \\
\hline $2020 \ldots \ldots \ldots \ldots \ldots \ldots \ldots \ldots$ & 110,811 & 19,303 & 17,678 & 17,068 & 19,268 & 17,986 & 18,696 & 17,880 \\
\hline $2019 \ldots \ldots \ldots \ldots \ldots \ldots \ldots$ & 116,289 & 19,628 & 17,975 & 17,975 & 19,910 & 19,261 & 20,168 & 19,347 \\
\hline \multicolumn{9}{|l|}{ Native Hawaiian or Pacific Islander: } \\
\hline $2021^{3} \ldots \ldots \ldots \ldots \ldots \ldots$ & 4,413 & 799 & 616 & 616 & 753 & 731 & 806 & 708 \\
\hline$\ldots \ldots \ldots \ldots \ldots \ldots \ldots$ & 4,665 & 803 & 786 & 759 & 794 & 705 & 820 & 757 \\
\hline $2019 \ldots \ldots \ldots \ldots \ldots \ldots \ldots$ & 4,695 & 790 & 762 & 762 & 814 & 738 & 847 & 744 \\
\hline \multicolumn{9}{|l|}{ Hispanic ${ }^{5}$} \\
\hline $2021^{3}$. & 409,941 & 65,687 & 61,961 & 61,961 & 70,060 & 68,202 & 70,722 & 73,309 \\
\hline$\ldots \ldots \ldots \ldots \ldots$ & 420,563 & 73,601 & 67,466 & 65,140 & 70,361 & 68,000 & 70,085 & 71,050 \\
\hline $2019 \ldots \ldots \ldots \ldots \ldots \ldots \ldots \ldots$ & 421,991 & 73,742 & 65,667 & 65,667 & 70,442 & 68,517 & 72,747 & 70,876 \\
\hline All races and origins ${ }^{2}$ & \multicolumn{8}{|c|}{ Percent change } \\
\hline $2020-2021 \ldots \ldots \ldots \ldots \ldots \ldots \ldots$ & -2 & -9 & -6 & -2 & †0 & 1 & -1 & 3 \\
\hline $2019-2020 \ldots \ldots \ldots \ldots \ldots \ldots \ldots$ & -2 & -2 & 1 & -3 & -1 & -3 & -5 & -1 \\
\hline \multicolumn{9}{|l|}{ Non-Hispanic, single race ${ }^{4}$} \\
\hline \multicolumn{9}{|l|}{ White: } \\
\hline 2020-2021 . & †0 & -7 & -3 & †0 & 2 & 2 & †0 & 4 \\
\hline 2019-2020 . & -2 & -3 & $\dagger 1$ & -3 & -1 & -4 & -5 & -1 \\
\hline \multicolumn{9}{|l|}{ Black: } \\
\hline $2020-2021 \ldots \ldots \ldots \ldots \ldots \ldots \ldots$ & -5 & -11 & -8 & -5 & -4 & -4 & -5 & $\dagger-1$ \\
\hline $2019-2020 \ldots \ldots \ldots \ldots \ldots \ldots \ldots$ & -1 & -2 & $\dagger 1$ & -2 & †0 & -2 & -4 & $\dagger 1$ \\
\hline \multicolumn{9}{|l|}{ American Indian or Alaska Native: } \\
\hline $2020-2021 \ldots \ldots \ldots \ldots \ldots \ldots \ldots$ & -6 & -7 & $\dagger-6$ & $\dagger-2$ & $\dagger-1$ & $\dagger-4$ & -12 & $\dagger-2$ \\
\hline $2019-2020 \ldots \ldots \ldots \ldots \ldots \ldots$ & -6 & -9 & -6 & -9 & $\dagger-5$ & $\dagger-4$ & -6 & $\dagger-2$ \\
\hline \multicolumn{9}{|l|}{ Asian: } \\
\hline $2020-2021 \ldots \ldots \ldots \ldots \ldots \ldots \ldots$ & -8 & -19 & -13 & -10 & -6 & -3 & -6 & $\dagger 2$ \\
\hline $2019-2020 \ldots \ldots \ldots \ldots \ldots \ldots \ldots$ & -5 & $\dagger-2$ & $\dagger-2$ & -5 & -3 & -7 & -7 & -8 \\
\hline \multicolumn{9}{|l|}{ Native Hawaiian or Pacific Islander: } \\
\hline $2020-2021 \ldots \ldots \ldots \ldots \ldots \ldots \ldots$ & -5 & †0 & -22 & -19 & $\dagger-5$ & $\dagger 4$ & $\dagger-2$ & $\dagger-6$ \\
\hline $2019-2020 \ldots \ldots \ldots \ldots \ldots \ldots \ldots$ & $\dagger-1$ & $\dagger 2$ & $\dagger 3$ & †0 & $\dagger-2$ & $\dagger-4$ & $\dagger-3$ & $\dagger 2$ \\
\hline \multicolumn{9}{|l|}{ Hispanic $^{5}$} \\
\hline $2020-2021 \ldots \ldots \ldots$ & -3 & -11 & -8 & -5 & †0 & †0 & $\dagger 1$ & 3 \\
\hline $2019-2020 \ldots \ldots \ldots$ & †0 & †0 & 3 & $\dagger-1$ & †0 & $\dagger-1$ & -4 & †0 \\
\hline
\end{tabular}

† No significant change $(p<0.05)$.

0 Quantity more than zero but less than 0.5 .

${ }^{1}$ Number of births for February 2020 adjusted for leap day, February 29

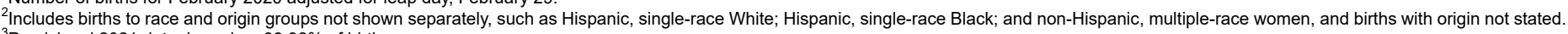
${ }^{3}$ Provisional 2021 data; based on $99.92 \%$ of births.

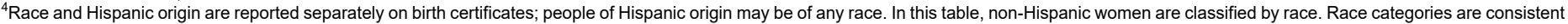
with the 1997 Office of Management and Budget standards. Single race is defined as only one race reported on the birth certificate.

${ }^{5}$ Includes all people of Hispanic origin of any race.

SOURCE: National Center for Health Statistics, National Vital Statistics System, Natality.

U.S. Department of Health and Human Services $\bullet$ Centers for Disease Control and Prevention $\bullet$ National Center for Health Statistics $\bullet$ National Vital Statistics System 
Table 2. Births: United States and each state, January-June, final 2019 and 2020, and provisional 2021, and percent change in births from January-June 2019-2020 and 2020-2021

\begin{tabular}{|c|c|c|c|c|c|}
\hline \multirow[b]{2}{*}{ Reporting area } & \multicolumn{5}{|c|}{ January-June } \\
\hline & 2019 & 2020 & $2021^{1}$ & 2019-2020 & 2020-2021 \\
\hline & \multicolumn{3}{|c|}{ Number } & \multicolumn{2}{|c|}{ Percent change } \\
\hline$\ldots \ldots \ldots \ldots \ldots \ldots \ldots \ldots$ & $1,814,497$ & $1,783,124$ & $1,748,768$ & -2 & -2 \\
\hline Alabama $\ldots \ldots \ldots \ldots \ldots \ldots \ldots \ldots$ & 27,778 & 28,055 & 27,637 & $\dagger 1$ & $\dagger-1$ \\
\hline Alaska. . . . . $\ldots \ldots \ldots \ldots \ldots \ldots$ & 4,881 & 4,712 & * & $\dagger-3$ & $\ddagger$ \\
\hline$\ldots \ldots \ldots \ldots \ldots \ldots \ldots \ldots$ & 38,168 & 37,441 & 36,077 & -2 & -4 \\
\hline$\ldots \ldots \ldots \ldots \ldots \ldots \ldots \ldots$ & 17,439 & 17,194 & 16,882 & $\dagger-1$ & $\dagger-2$ \\
\hline California $\ldots \ldots \ldots \ldots \ldots \ldots \ldots \ldots$ & 216,456 & 207,163 & 198,964 & -4 & -4 \\
\hline 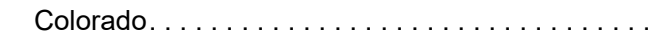 & 30,590 & 30,524 & 30,977 & †0 & $\dagger 1$ \\
\hline$\ldots \ldots \ldots \ldots \ldots \ldots \ldots \ldots$ & 16,752 & 16,617 & 17,110 & $\dagger-1$ & 3 \\
\hline Delaware & 4,963 & 5,061 & 4,859 & $\dagger 2$ & -4 \\
\hline District of Columbia & 4,364 & 4,470 & 4,088 & $\dagger 2$ & -9 \\
\hline Florida $\ldots \ldots \ldots \ldots \ldots \ldots \ldots \ldots \ldots$ & 105,184 & 102,493 & 100,977 & -3 & -1 \\
\hline$\ldots \ldots \ldots \ldots \ldots \ldots \ldots \ldots$ & 60,855 & 60,051 & 58,863 & -1 & -2 \\
\hline$\ldots \ldots \ldots \ldots \ldots \ldots \ldots \ldots$ & 8,191 & 7,837 & 7,535 & -4 & -4 \\
\hline Idaho & 10,896 & 10,645 & 10,984 & $\dagger-2$ & 3 \\
\hline$\ldots \ldots \ldots \ldots \ldots \ldots \ldots \ldots$ & 68,353 & 66,113 & 64,624 & -3 & -2 \\
\hline$\ldots \ldots \ldots \ldots \ldots \ldots \ldots \ldots$ & 38,992 & 38,864 & 37,877 & †0 & -3 \\
\hline lowa $\ldots \ldots \ldots \ldots \ldots \ldots \ldots \ldots$ & 18,518 & 18,025 & 17,795 & -3 & $\dagger-1$ \\
\hline$\ldots \ldots \ldots \ldots \ldots \ldots \ldots$ & 17,130 & 16,926 & 16,718 & $\dagger-1$ & $\dagger-1$ \\
\hline$\ldots \ldots \ldots \ldots \ldots \ldots$ & 25,520 & 25,227 & 24,990 & $\dagger-1$ & $\dagger-1$ \\
\hline Louisiana $\ldots \ldots \ldots \ldots \ldots \ldots \ldots \ldots$ & 27,849 & 27,634 & 27,215 & $\dagger-1$ & $\dagger-2$ \\
\hline 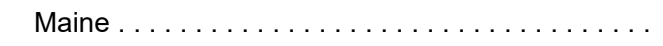 & 5,772 & 5,683 & 5,775 & $\dagger-2$ & $\dagger 2$ \\
\hline Maryland . . . . . . . . . . . . . . . . . . & 34,035 & 34,014 & 32,786 & †0 & -4 \\
\hline Massachusetts . . . . . . . . . . . . . . . . & 33,601 & 33,366 & 33,396 & $\dagger-1$ & †0 \\
\hline Michigan . . . . . . . . . . . . . . . . . . & 53,014 & 52,286 & 50,769 & -1 & -3 \\
\hline Minnesota. $\ldots \ldots \ldots \ldots \ldots \ldots \ldots \ldots \ldots$ & 32,474 & 31,800 & 31,355 & -2 & $\dagger-1$ \\
\hline Mississippi $\ldots \ldots \ldots \ldots \ldots \ldots \ldots \ldots \ldots$ & 17,233 & 17,193 & 16,667 & †0 & -3 \\
\hline 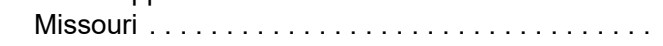 & 35,046 & 34,234 & 33,595 & -2 & -2 \\
\hline$\ldots \ldots \ldots \ldots \ldots \ldots \ldots$ & 5,546 & 5,499 & 5,543 & $\dagger-1$ & $\dagger 1$ \\
\hline$\ldots \ldots \ldots \ldots \ldots \ldots \ldots$ & 12,152 & 12,091 & 12,136 & $\dagger-1$ & †0 \\
\hline Nevada. . . . . . . . . . . . . . . . & 16,798 & 16,356 & 16,027 & -3 & $t-2$ \\
\hline New Hampshire $\ldots \ldots \ldots \ldots \ldots \ldots \ldots$ & 5,732 & 5,788 & 6,090 & $\dagger 1$ & 5 \\
\hline New Jersey. & 48,245 & 48,583 & 47,455 & $\dagger 1$ & -2 \\
\hline New Mexico $\ldots \ldots \ldots \ldots \ldots \ldots \ldots$ & 11,048 & 10,756 & 10,223 & -3 & -5 \\
\hline New York $\ldots \ldots \ldots \ldots \ldots \ldots \ldots \ldots$ & 107,791 & 105,532 & 101,688 & -2 & -4 \\
\hline North Carolina . . . . . . . . . . . . . . & 57,371 & 57,417 & 57,167 & †0 & †0 \\
\hline North Dakota $\ldots \ldots \ldots \ldots \ldots \ldots \ldots \ldots \ldots$ & 5,275 & 5,017 & 5,006 & -5 & †0 \\
\hline Ohio $\ldots \ldots \ldots \ldots \ldots \ldots \ldots \ldots \ldots$ & 65,303 & 63,879 & 62,900 & -2 & -2 \\
\hline Oklahoma. . . . . . $\ldots \ldots \ldots \ldots \ldots \ldots$ & 23,607 & 23,371 & 23,225 & $\dagger-1$ & $\dagger-1$ \\
\hline Oregon $\ldots \ldots \ldots \ldots \ldots \ldots \ldots \ldots \ldots$ & 20,937 & 19,999 & 19,801 & -4 & $\dagger-1$ \\
\hline Pennsylvania $\ldots \ldots \ldots \ldots \ldots \ldots \ldots \ldots \ldots$ & 65,204 & 64,667 & 63,969 & $\dagger-1$ & $t-1$ \\
\hline Rhode Island $\ldots \ldots \ldots \ldots \ldots \ldots \ldots$ & 4,993 & 5,064 & 4,987 & $\dagger 1$ & $\dagger-2$ \\
\hline South Carolina & 27,515 & 27,152 & 27,230 & $\dagger-1$ & †0 \\
\hline South Dakota & 5,686 & 5,520 & 5,641 & $\dagger-3$ & $\dagger 2$ \\
\hline$\ldots \ldots \ldots \ldots \ldots \ldots \ldots$ & 38,715 & 38,248 & 38,968 & $\dagger-1$ & 2 \\
\hline Texas $\ldots \ldots \ldots \ldots \ldots \ldots \ldots \ldots \ldots$ & 179,973 & 178,420 & 174,494 & -1 & -2 \\
\hline $\operatorname{Utah} \ldots \ldots \ldots \ldots \ldots \ldots \ldots \ldots \ldots$ & 23,175 & 23,084 & 22,682 & †0 & $\dagger-2$ \\
\hline Vermont $\ldots \ldots \ldots \ldots \ldots \ldots \ldots \ldots \ldots$ & 2,689 & 2,580 & 2,615 & $\dagger-4$ & $\dagger 1$ \\
\hline$\ldots \ldots \ldots \ldots$ & 47,295 & 46,863 & 46,329 & $\dagger-1$ & $\dagger-1$ \\
\hline Washington $\ldots \ldots \ldots \ldots \ldots \ldots \ldots \ldots$ & 42,165 & 41,484 & 40,906 & -2 & -1 \\
\hline West Virginia $\ldots \ldots \ldots \ldots \ldots \ldots \ldots \ldots \ldots$ & 8,767 & 8,530 & 8,273 & $\dagger-3$ & -3 \\
\hline Wisconsin $\ldots \ldots \ldots \ldots \ldots \ldots \ldots \ldots \ldots$ & 31,144 & 30,568 & 30,152 & -2 & $\dagger-1$ \\
\hline Wyoming $\ldots \ldots \ldots \ldots \ldots \ldots \ldots \ldots$ & 3,317 & 3,028 & 3,062 & -9 & $\dagger 1$ \\
\hline
\end{tabular}

$\dagger$ No significant change $(p<0.05)$.

* Estimate does not meet NCHS standards of reliability; data do not meet reporting standards of $85 \%$ or higher.

$\ddagger$ Difference not calculable; data not reported.

0 Quantity more than zero but less than 0.5 .

${ }^{1}$ Provisional 2021 data; based on $99.92 \%$ of births.

SOURCE: National Center for Health Statistics, National Vital Statistics System, Natality. 


\section{Acknowledgments}

This report was prepared in the Division of Vital Statistics (DVS) under the general direction of Steven Schwartz, Director; Isabelle Horon, Chief, Reproductive Statistics Branch (RSB); and Joyce Martin, Team Leader, RSB Birth Team. Rajesh Virkar, Chief, Information Technology Branch (ITB), and Steve J. Steimel, Annie S. Liu, Jasmine N. Mickens, and Legesse Alemu provided computer programming support and statistical tables. Steve J. Steimel and Annie S. Liu of ITB prepared the natality file. The Data Acquisition, Classification and Evaluation Branch staff of DVS evaluated the quality of and acceptance procedures for the state data files on which this report is based. Anne K.

Driscoll of RSB provided content review.

\section{Suggested citation}

Hamilton BE, Osterman MJK, Martin JA. Changes in births by month: United States, January 2019-June 2021. Vital Statistics Rapid Release; no 19. Hyattsville, MD: National Center for Health Statistics. March 2022. DOI: https://dx.doi.org/10.15620/cdc:113283.

\section{Copyright information}

All material appearing in this report is in the public domain and may be reproduced or copied without permission; citation as to source, however, is appreciated.

\section{National Center for Health Statistics}

Brian C. Moyer, Ph.D., Director

Amy M. Branum, Ph.D., Associate

Director for Science

\section{Division of Vital Statistics}

Steve Schwartz, Ph.D., Director

Isabelle Horon, Dr. P.H., Acting

Associate Director for Science 